\title{
OPTIMIZATION OF THE MANAGEMENT MECHANISM FOR THE INNOVATIVE DEVELOPMENT OF THE REGION'S AGRICULTURAL SECTOR
}

\begin{abstract}
Oksana MAMAI, Department of Management and marketing, Faculty of Economics Samara State Agricultural Academy, 446442 Uchebnaya St., 2, Ust-Kinelskiy, Samara Region, Russia; mamai_ov@ ssaa.ru (corresponding author)

Igor MAMAI, Department of Management and marketing, Faculty of Economics Samara State Agricultural Academy, 446442 Uchebnaya St., 2, Ust-Kinelskiy, Samara Region, Russia; mamai in@ ssaa.ru
\end{abstract}

\begin{abstract}
The current trends in the development of innovative activities in Russia are far from fully meeting the expectations associated with improving the competitiveness of products and the quality of life of the population, with the provision of dynamic sustainable growth, and the formation of the innovative economy. The mixed nature of the Russian economy, the fundamentally different technological level and institutional conditions for the development of various sectors exclude the possibility of defining a single model of innovative development that is universal for all sectors. In the current conditions, the technical and technological level of the agrarian sector of the country's economy is the most catastrophically lagging behind the world's leading producers of agricultural products. Domestic agrarian production is 5 times more energy intensive and 4 times more metal consuming, and labor productivity is 8-10 times lower than in the USA, in the leading countries of the European Union and Canada. Not having eliminated this techno-technological backlog, without implementing the advanced development of certain specific areas of scientific research and technological developments in the field of agriculture, Russia's agrarian sector will finally lose its competitiveness and will not be able to ensure the country's food security. Thus, the need for a scientific justification of the theory, methodology and practice of the innovative development management of the agrarian sector of the regional economy in the context of large-scale economic and institutional transformations determines the urgency of the issue. Currently, most of the works of domestic researchers put emphasis on the problems of knowledge transfer, at the same time, the methodology for creating and commercializing competitive scientific knowledge through the formation of innovative agricultural clusters is beyond the scope of scientific research, and its management and economic mechanism has not been developed yet. Thus, the aim of this research is to develop proposals for optimization of the management mechanism for the innovative development of the region's agricultural sector (by the example of the Samara Region of the Russian Federation). The research used a set of methods of scientific knowledge used at both theoretical and empirical levels (conceptual modeling, synthesis and analysis, tabular and graphical interpretation of theoretical information and empirical data).
\end{abstract}

Keywords: agricultural sector, innovations, innovative solution, information and advisory services

\section{INTRODUCTION}

Innovative modernization of national economic systems, inherent changes in economic relations and infrastructure support are the subject of scientific research since the 1970-s of the XX century. At the same time, the impact of innovative modernization results and their adaptation to special aspects of the functioning of all life spheres of society determined the interdisciplinary nature of the research, became the object of study of economists, sociologists, managers, political scientists and culturologists (Bautin et al., 2003; Chayanov, 1924; Druker, 2007; Gohberg et al., 2010; Kondratev, 1993; Kuzyik, 2009; Raj, 2007; Schumpeter, 1961; Ushachev, 2005; Valdaytsev, 1997; Yakovets, 1991). However, many issues related to managing the innovative development of the agricultural sector of the regional economy are still insufficiently analyzed. Organizational mechanisms of the innovative development of the agricultural economy, interaction of economic and technological factors in innovative conditions are not studied well. Mechanisms for creating the innovative environment in the agricultural sector have not been developed yet. At present, there is no generally accepted idea of the structure, functions and mechanisms for the formation of agricultural innovative clusters and how to realize their competitive advantages. We need to develop the concept of the agricultural innovative cluster as the basis for ensuring a gradual transition of the agricultural sector of the regional economy to the innovative development path. The issues under study and their interdependence actualize the formation of the regional innovative system of the agricultural sector and its adaptation to the changing regional conditions of reproduction, which necessitates carrying out empirical studies that allow approving approbation of the developed models and methodologies, identifying tools for their application and giving them an applied character. Thus, the aim of this research is to develop proposals for optimization of the distribution, and reproduction in any medium, provided the original author and source are credited. 
management mechanism for the innovative development of the region's agricultural sector (by the example of the Samara Region of the Russian Federation)

\section{METHODS}

The theoretical and methodological basis of the research is based on the works of domestic and foreign scientists who have made a significant contribution to the scientific solution of the problem of the innovative development of the Russian economy in general and the agricultural sector in particular. Various methods of studying processes and phenomena in the field of organizational and economic relations are used in the work. Such a complex approach includes a set of methods of scientific knowledge used at both theoretical and empirical levels (conceptual modeling, synthesis and analysis, tabular and graphical interpretation of theoretical information and empirical data). Systemic, program-target, institutional, evolutionary and logical approaches to studying trends in the development of the innovative system of the agricultural sector of the regional economy, as well as monographic, computational and economic and statistical research methods were applied.

\section{RESULTS}

In the management system of the region's innovative development, as the study showed (Mamai, 2009; OECD, 2011), the main place is given to information and consulting support of this process. At the same time, the successful functioning of the information and advisory services organization (IASO) in the region's innovative development concerning the agricultural sector is impossible without a clear organizational mechanism. The basis is the creation of the bank of innovative and informational and advisory needs of agricultural enterprises in the region.

There are two criteria for determining the list of services offered by the IASO to potential customers:

1) Services that employees of the IASO can provide independently or with the help of attracted specialists,

2) Services that are currently required for potential customers.

In accordance with the first criterion, it is possible to create a list of services provided, if the advisor clearly understands what functions he should perform at his workplace and what knowledge and skills he has to satisfy these requirements.

The essence of the second criterion is often misunderstood by advisors, and then these services rendered by the service fall into the list that can be provided by advisors in the most effective way, rather than those that are really needed by commodity producers at present.

For example, many large agricultural enterprises do not need help on highly specialized issues (compiling crop rotations, feeding diets, etc.), as they usually have their own staff specialists (agronomist, livestock specialist, engineer, etc.). Therefore, enterprises need comprehensive assistance in resolving the issues of introducing and adapting innovative technologies and the latest achievements of science and technology, legal issues, taxation, environmental protection, organization of production, crediting, improving the quality of leadership, etc. Thus, when forming the list of information and advisory services provided, it is important to remember that clients (agribusinesses) should determine the subject and form of information products transfer and services (Aleksanov et al., 2001). Therefore, all clients should be divided into target groups, as each of them has its own goals and needs specific information.

The survey of agricultural enterprises' needs and requirements in the agricultural sector of the Samara region in information and advisory services was carried out using direct methods of studying, which made it possible to reveal the real interest of agricultural producers in the agricultural sector (Mamai, 2009; Mamai et al., 2015). For this purpose, a sociological survey of managers and specialists of agricultural enterprises of the Samara region was conducted.

This research was based on the methodology of studying information and advisory activities, which was tested in the Republic of Kazakhstan (Stukach et al., 2000). The survey included the following stages:

1) Questioning of managers and specialists of agricultural enterprises to identify the severity of specific needs in a particular information and advisory service, which allowed determining the range of services that they currently need;

2) Based on the results of the previous stage, differentiation of information and advisory needs of managers and specialists by types was carried out;

3) Based on the received information it became possible to determine the potential capacity of the market of information and advisory services and their indicative structure by types;

4) Managers of agricultural enterprises of the region's agricultural sector were also interviewed about the organizational arrangement of information and advisory services.

The survey was attended by managers and specialists of agricultural enterprises from all 27 districts of the Samara region. As for basic education all respondents were distributed as follows: engineers $-40.4 \%$; agronomists $-39.0 \%$; zoogenerators $-11.8 \%$; economists $-3.9 \%$; scientists $-0.7 \%$; leaders with higher party education $-0.7 \%$; accountants $0.7 \%$; teachers $-0.7 \%$; economists - zootechnicians $-0.7 \%$; others $-1.4 \%$.

Among those surveyed, $87.0 \%$ had higher education and $13.0 \%$ had secondary special education.

Most commonly all professional groups are in need for the following information:

- Cost accounting and cost analysis $-88.9 \%$;

- Information on prices $-81.8 \%$;

- Business planning $-80.2 \%$. 
The revealed results indicate the lack of the developed system of information support for the agricultural sector of the Russian economy.

Leaders and specialists of agricultural enterprises, depending on their basic education, experience the following information and advisory needs:

1) Engineers need information and advisory services on interaction with tax services $-79.3 \%$, on the newest technologies of crop management $-77.5 \%$, on the use of new varieties of plants and animal breeds $-75.5 \%$;

2) Zooengineers need information on the purchase of equipment $-84.9 \%$ and seeds $-78,9 \%$, on the use of modern equipment $-72.8 \%$;

3) Agronomists need information on interaction with tax services $-88.3 \%$, on prices in markets $-86.0 \%$, on the purchase of seeds $-82.7 \%$

4) Economists need information on the use of legislative acts in resolving possible conflicts $-87.9 \%$, on the possibility of obtaining loans $-83.0 \%$. follows:

Summarizing the above, it can be concluded that, according to the priority, information and advisory needs are as

1) Information on prices in markets, sales of products, analytical and economic services (74.2\%);

2) Services of external advisors on specific issues: on technological processes in plant growing, livestock, including taking into account innovative developments, on repair, purchase of machinery, seeds, fertilizers, pesticides $(59,9 \%)$.

3) Legal and tax-legislative advisory services (58, 3\%) (Figure 1).

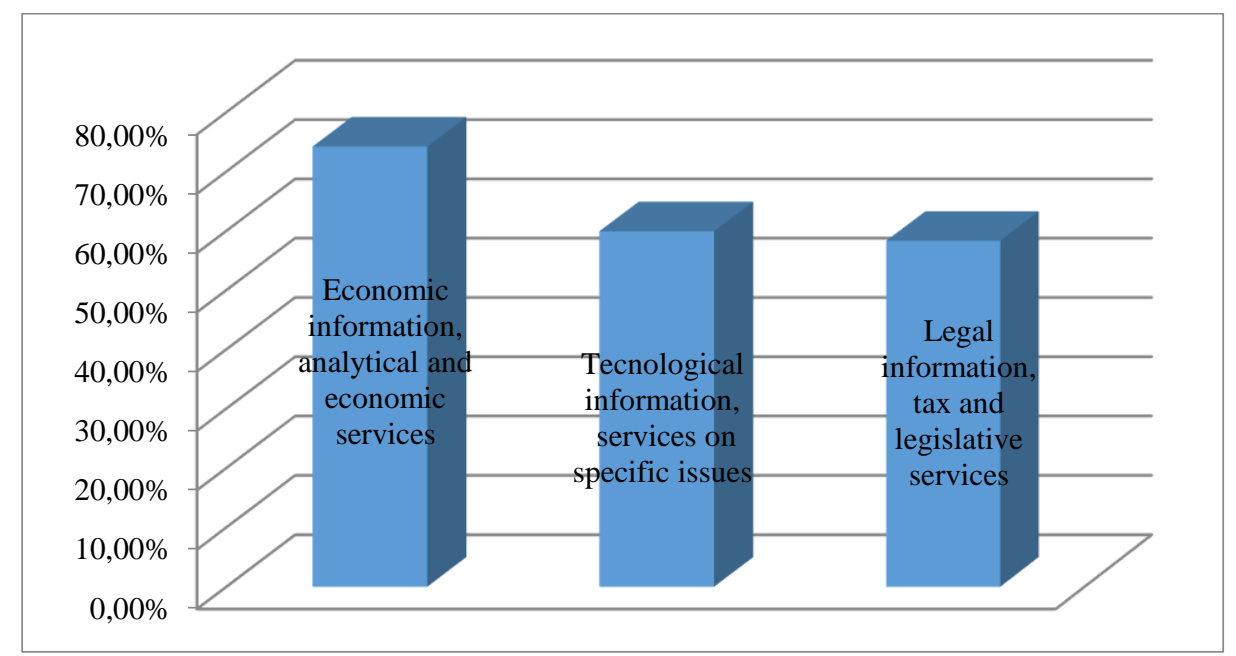

Figure. 1. Information and advisory needs of agricultural enterprises of the agricultural sector in the Samara region

It turned out that $98.2 \%$ of surveyed managers and specialists of agricultural enterprises in the Samara region are ready to cooperate with information and advisory services.

Using the information obtained, it is possible to determine the potential capacity of the information and advisory services market. The conducted research showed that agricultural enterprises in all districts of the region are interested in advisory services. It is important to remember that the location of enterprises of the agricultural sector in various natural and climatic zones influences their activities and contributes to the emergence of specific problems for them, which should be taken into account when organizing the work of advisory services.

For example, enterprises located in the central zone of the Samara region have the opportunity to visit any scientific, educational, research institution in city of Samara and obtain the required information and advice. Even taking into account the time spent on multiple trips to the city, searching for the right specialist, concluding relevant contracts, etc., such enterprises are able to get the necessary help, thanks to the proximity to the regional center. Enterprises from the southern and northern zones are deprived of this opportunity because of their remote location from the city of Samara. Sometimes managers and specialists (who come from remote places) cannot get the necessary information because it is in the impossible form or because it is complete unavailable, or the above-mentioned institutions are unwilling to cooperate and there is lack of necessary specialists and etc. Information and advisory services are clearly preferable in this case, since any manager or specialist who appeals to them for help will receive the required information and advice at the right time, in the right amount and the right quality.

The opinion of managers and specialists of the region's agricultural sector on the organizational and legal form of the IASO is extremely important (Figure 2).

The diagram shows that $57.0 \%$ of respondents preferred the state form of the IASO; $35 \%$ of respondents believe that the IASO should be independent organizations; $8.0 \%$ of respondents prefer private practitioners. This indicates a greater confidence on the part of managers and specialists of the agricultural sector to state information and advisory services, since in this case the state is responsible for the quality of the information and services provided. 
Private practice of a single advisor $8 \%$

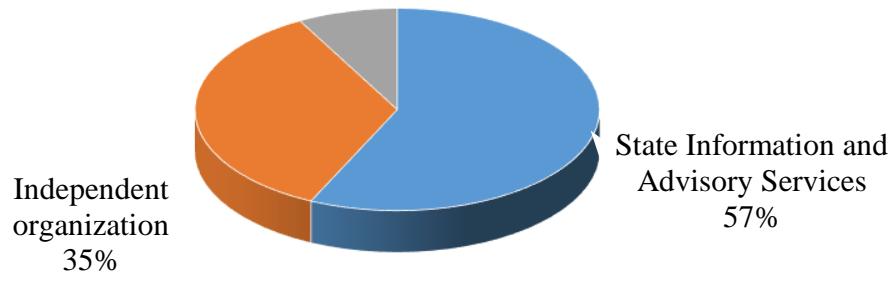

Figure 2. The respondents' choice of organizational and legal form of information and advisory services in the Samara region

However, the world practice shows that information and advisory services should be independent of any organizations, government bodies, state intervention, etc., which will allow freely and independently addressing issues related to interaction with enterprises of the region's agricultural sector.

The conducted research made it possible to identify the opinion of managers and specialists of agricultural enterprises of the region' $s$ agricultural sector regarding their readiness and ability to pay for certain types of services (Figure 3).

Prefer the mixed system $29 \%$

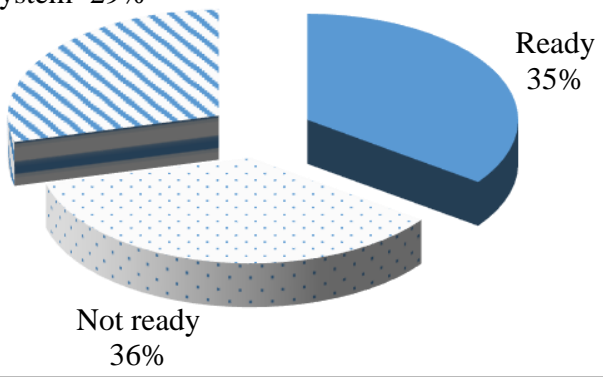

Figure 3. The respondents' readiness to pay for information and advisory services in the Samara region

Fig. 3 shows that $36 \%$ of respondents prefer to receive completely free information and advisory services; $35 \%$ of respondents expressed their readiness to pay for information and advisory services; $29 \%$ consider it is necessary to introduce a mixed payment system.

Consequently, for the effective operation of the IASO, various methods and forms of payment for information and advisory services are required. This is primarily necessary to implement a differentiated approach to providing services to agricultural enterprises of the region's agricultural sector with different economic situations and information and advisory needs.

This allows stating as follows:

- The idea of creating and operating regional information and advisory organization is supported by almost all managers and specialists of the region's agricultural sector;

- The created organization should provide both paid and free information and advisory services;

- The state should act as a founder in the creation and control of the organization's activity.

Taking into account the results obtained during the research, it is necessary to develop specific measures for the operation of the IASO. For this purpose, in accordance with the methodology of the Russian Central Research Institute of Innovative Problems and Marketing in the Agro-industrial Complex (Lazovskiy, 1996), the authors monitored information and advisory services currently in demand. For this purpose, the following tasks were set and solved:

1) Analyze the current system of information and advisory services for agricultural enterprises of the region's agricultural sector;

2) On the basis of information and advisory needs of managers and specialists of agricultural enterprises of the region's agricultural sector, form a typical bank of problems and the corresponding list of services provided by the IASO with the allocation of paid services;

3) Identify the needs of managers and specialists of agricultural enterprises of the region's agricultural sector to improve their qualifications and identify the most preferable subjects of training.

The score was as follows: 5 - very important, 4 - important, 3 - interesting, 2 - could be interesting, 1 - slightly interesting, 0 - not interesting.

The results of the study are presented below. Managers and specialists of agricultural enterprises of the region's agricultural sector now use four main sources of information. They are ranked as follows:

1) Government bodies and other state organizations;

2) Advisory services;

3) Individual advisors;

4) Private advisory organizations.

It is characteristic that these sources are relatively low used. The average score was 1,9 on a five-point scale. This indicates that the currently available sources of information poorly satisfy information and advisory needs of agricultural enterprises. 
The mass media are informative (on average - 2.4) to managers and specialists of agricultural enterprises of the region's agricultural sector. The most preferable among them are press and television (3.6 and 3.1, respectively). The basic communication means are still the telephone (3.4), and seminars (3.5) take an important place among scientific and practical events.

As a result of the research, the most preferred sources of information were identified. The most accessible source of information for managers and specialists of agricultural enterprises of the region's agricultural sector was television (3.2). Such sources as advisors, press and seminars (an average 3.0) were close to be important. The least interest as a source of information was caused by the radio (2.5).

The study of the frequency of obtaining information by managers and specialists of agricultural enterprises of the region's agricultural sector from various sources had disappointing results. Most often, information is obtained periodically. The respondents receive information from specialists of the Ministry of Agriculture and Food of the Region $(82.7 \%)$ and information and advisory services $(56.0 \%)$. They constantly receive information from the radio $-39.7 \%$ of respondents, from television $-49.1 \%$, from the press $-48.2 \%$. Information from exhibitions is rarely received $(54.5 \%)$. However, the number of respondents who gave similar answers is small, which indicates the occasional obtaining of information from various sources. At the same time, managers and specialists of agricultural enterprises of the region's agricultural sector consider the advisors' visits to their enterprises (75.8\%) and enterprises' independent visits to information and advisory services organizations (59.9\%) as the most optimal forms of information and advisory services.

From the presented list of information and advisory services, respondents noted services that could be provided on a fee basis: providing information on current prices for agricultural products in all types of markets (85.9\%), taxation services (79.0\%), information on bank loans and financial transactions (71.8\%), the business plan development (71.1\%), agrochemical research of soil, water, feed, product quality (70.\%), etc., advisory services on improving the efficiency of production activities and economic problems (61.3\%), marketing services $(54.6 \%)$, market information on prices, demand, competitors $(49.4 \%)$, etc. The most preferable prices for services are prices partially compensated by the state $(66.4 \%)$, and fixed prices (60.7\%). Managers and specialists of agricultural enterprises of the region's agricultural sector expressed a desire to pay for services provided by transferring money to the account of the information and advisory services organization $(77.4 \%)$, while seasonal contracts are considered to be the most acceptable medium term (63.0\%), and one-time calls to advisory service if it is necessary $(56.3 \%)$.

Respondents showed particular interest in receiving printed information and advisory products (newspapers, information sheets, magazines, etc.). In this case, magazines were the most preferable (61, 5\% of respondents). Managers and specialists of agricultural enterprises of the region's agricultural sector noted that they would be interested in various refresher courses organized by the IASO (Figure 4). Among the topics for them were the following issues: the use of new machinery and technologies in crop production (84, 1\%), taxation of legal and physical persons (82.2\%), marketing and entrepreneurship (79.5\%), organization and management of breeding business $(78.7 \%)$, prevention and treatment of diseases of farm animals (76.3\%), legal support for agricultural enterprises' activity (76.1\%), the use of new machinery and technologies in livestock $(75.1 \%)$, enterprises $(74.9 \%)$, car repairs, tractors and agricultural machines $(72.6 \%)$, enhance the efficiency of agricultural production through the use of advanced technologies, the introduction of new plant varieties and animal breeds, the use of fertilizers, herbicides, medicines, growth promoters (72.4\%), etc. At the same time, many managers and specialists of agricultural enterprises of the region's agricultural sector (76, $1 \%$ of respondents) are ready to fully pay for the above-mentioned courses.

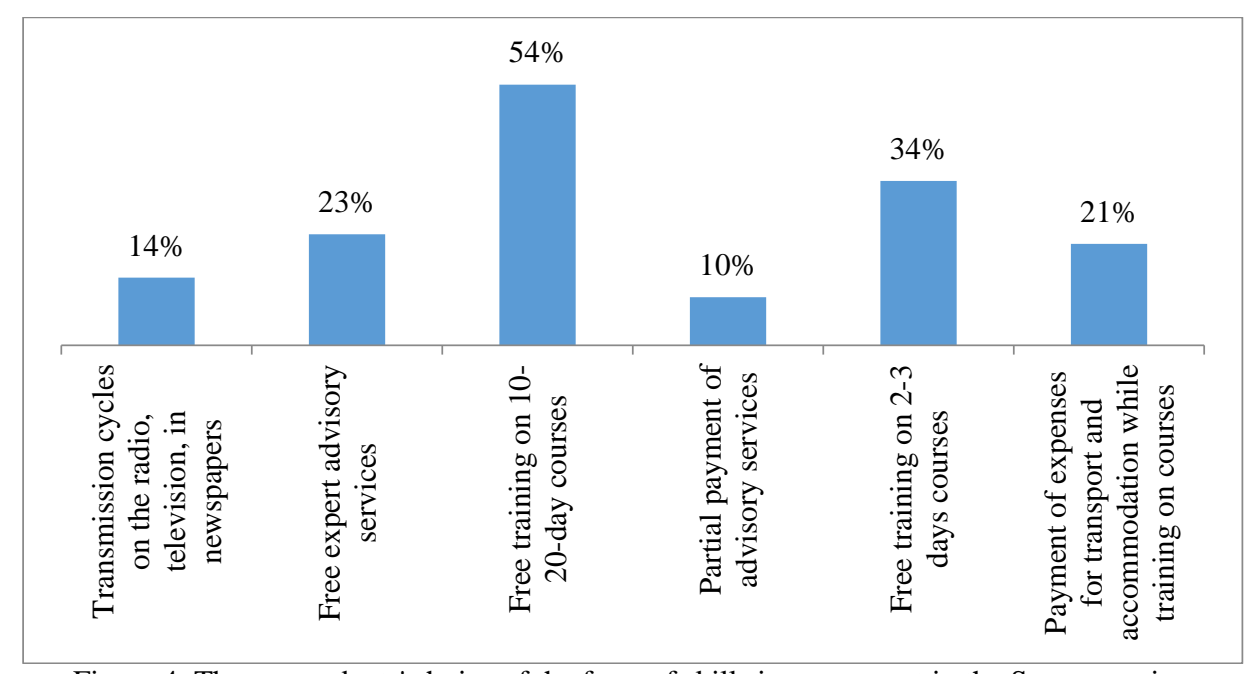

Figure 4. The respondents' choice of the form of skills improvement in the Samara region

Based on the information received, it became possible to form curricula and training programs and activities conducted by the IASO with the participation of Samara State Agricultural Academy, taking into account their relevance to potential participants in educational programs. 
Thus, the conducted studies show that managers and specialists of agricultural enterprises of the region's agricultural sector are interested in the innovative development of their economy, therefore, information and advisory support of this issue is one of the priority activities of the Samara IASO.

\section{DISCUSSION}

The presented research results can solve only a part of the issues connected with the optimization of the management mechanism for the innovative development of the region's agricultural sector. However, their application is possible with the formation of the region's innovative policy and the development of official policy documents in the innovation sphere by the government of the Samara region. The main provisions can be applied: when forming innovative strategies for the region's agricultural sector development by the governments of the entities of the Russian Federation; when developing innovative development programs for the agricultural sector of the regional economy; when deciding on the key investment points of funds.

\section{CONCLUSION}

Summarizing the aforesaid, it can be concluded that the conducted studies have made it possible to develop recommendations for optimization of the management mechanism for the innovative development of the region's agricultural sector (by the example of the Samara Region of the Russian Federation):

a) to determine the range of information and advisory services that managers and specialists of agricultural enterprises currently need;

b) to differentiate the information and advisory needs of managers and specialists by types;

c) to determine the potential capacity of the market of information and advisory services and their indicative structure by types;

d) to optimize the organizational structure of information and advisory services;

e) to investigate the current system of information and advisory services for agricultural enterprises of the region's agricultural sector;

f) to form a typical bank of problems and the corresponding list of services provided by the IASO with the allocation of paid services on the basis of information and advisory needs of managers and specialists of agricultural enterprises of the region's agricultural sector;

g) to identify the needs of managers and specialists of agricultural enterprises of the region's agricultural sector to improve their qualifications and identify the most preferable subjects of training.

\section{REFERENCES}

1. Aleksanov, D., Koshelev, V. 2001. Konsultirovanie selskohozyaystvennyih tovaroproizvoditeley po ekonomike i upravleniyu (Consultation of agricultural producers on economy and management). Moscow. [In Russian]

2. Bautin, V., Kozlov, V., Kozlova, E. 2003. Innovatsionnaya deyatelnost v selskohozyaystvennom konsultirovanii regiona. (Innovative activity in agricultural consultation of the region). Moscow. [In Russian]

3. Chayanov, A. 1924. Osnovnyie idei i metodyi rabotyi obschestvennoy agronomii. (Main ideas and methods of work of public agronomics). Novaya derevnya, Moscow. [In Russian]

4. Druker, P. 2007. Biznes i innovatsii. (Business and innovations). Vilyams, Moscow. [In Russian]

5. Gohberg, L., Kuznetsova, T., Rud, V. 2010. Analiz innovatsionnyih rezhimov v rossiyskoy ekonomike. Metodologicheskie podhodyi i pervyie rezultatyi. (The analysis of the innovative modes in the Russian economy. Methodological approaches and first results). Forsayt, No. 3, pp. 18-30. [In Russian]

6. Kondratev, N.1993. Izbrannyie sochineniya (Chosen compositions). Ekonomika, Moscow. [In Russian]

7. Kuzyik, B. 2009. Innovatsionnoe razvitie Rossii: stsenarnyiy podhod (Innovative development of Russia: scenario approach). Economic strategies, Vol. 1, pp. 56-67. [In Russian]

8. Lazovskiy, V. 1996. Metodika monitoringa informatsionnyih potrebnostey selskih tovaroproizvoditeley (Technique of monitoring of information requirements of rural producers). Moscow. [In Russian]

9. Mamai, O. 2009. Metodologicheskie osnovyi innovatsionnogo razvitiya agrarnogo sektora regionalnoy ekonomiki (Methodological bases of innovative development of the agrarian sector of regional economy). Samara. [In Russian]

10. Mamai, O., Mamai, I. 2015. Teoreticheskie osnovyi innovatsionnogo razvitiya agrarnogo sektora regionalnoy ekonomiki (Theoretical bases of innovative development of the agrarian sector of regional economy). Kinel. [In Russian]

11. OECD. 2011, OECD Reviews of Innovation Policy: Russian Federation. Available at http://www.oecd-ilibrary.org/science-andtechnology/oecd-reviews-of-innovation-policy-russian-federation-2011_9789264113138-en

12. Raj, M. 2007. Desai Enhancing Russia's Competitiveness and Innovative Capacity. Finance and Private Sector Development Department. Europe and Central Asia Region. Document of the World Bank, pp. 30-32.

13. Schumpeter, Y. 1961. Theory of Economic Development. Oxford University Press.

14. Stukach, V., Shulenbaeva, F. 2000. Informatsionno-konsultatsionnyie uslugi v selskom hozyaystve (Information and consulting services in agriculture). [In Russian] 
15. Ushachev, I. 2005. Problemyi formirovaniya sistemyi upravleniya innovatsionnoy deyatelnostyu v APK (Problems of formation of a control system of innovative activity in agrarian and industrial complex). Proceedings of the International Scientific Conference "Innovatsionnaya deyatelnost v APK: opyit i problemyi" (Innovative activity in agrarian and industrial complex: experience and problems), 3-8, Moscow. [In Russian]

16. Ushachev, I. Trubilin, I, Ogloblin, E., Sandu, I. (eds.) 2007. Innovatsionnaya deyatelnost v agrarnom sektore ekonomiki Rossii (Innovative activity in the agrarian sector of economy of Russia). Koloss, Moscow. [In Russian]

17. Valdaytsev, S. 1997. Otsenka biznesa i innovatsii (Assessment of business and innovations). Filin', Moscow. [In Russian]

18. Yakovets, Yu. 1991. Uskorenie nauchno-tehnicheskogo progressa: Teoriya i ekonomicheskiy mehanizm (Acceleration of scientific and technical progress: Theory and economic mechanism). Ekonomika, Moscow. [In Russian] 